\title{
Financing The Firm: Venture Capital And Initial Public Offerings
}

Faramarz Damanpour (E-mail: damanpfx@jmu.edu), James Madison University Pete Mavrokordatos (E-mail: evanthis@ aol.com), Tarrant County College/University. of Phoenix

\begin{abstract}
Venture capital and initial public offerings have been the backbone of the development of new business firms for many years. However, the recent abnormal growth of stock market in the 1990s, especially the creation of the many new technology firms, has boosted venture capital formation and initial public offerings. This paper intends to shed light on the type and formation of the IPOs in 1999-2000, including the process involved, the stages of capital funding, the allotment pricing, and the risk and effects of flipping. It concludes with a brief discussion of the three new and successful IPOs.
\end{abstract}

\section{Introduction}

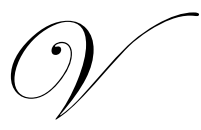

enture capital and venture capitalists have been the backbone of the development of new ideas and creation of the new business firms. It is a phenomenon that existed for many years but its productivity and gain have not been recognized until very recent years. Venture capitalists in the past mainly consisted of investment banking firms, investment companies, or very rich individuals who take risks by investing in new ideas, for healthy long-term returns. But in the recent years, while the aim and goal remained the same, the format has changed. First, the risk has increased because many of such investments are in the newly developed areas, mostly in biotech and technology. Second, the expectation also changed, as many of these investors are seeking a quicker and larger return. Third, the investors are not anymore limited to large investment companies and rich individuals, but instead it took entrepreneurial format, with many lower-wealth groups who seek to get involved in the adventure of participating in the new business ideas. Finally, the newly inventors are also becoming younger and less experienced in comparison to the older and seasoned inventors of the past.

Whenever stock in a closely held company is offered to the public for the first time, the company is said to be going public. The stock that is just being offered to the public is called the Initial Public Offering (IPO). Microsoft had its IPO in 1986. Previously, Bill Gates and other insiders owned all the shares. In many IPOs, the insiders sell some of their shares plus the company sells new shares to raise additional capital. IPOs have received a lot of attention in recent years, primarily because a number of hot issues have realized spectacular gains -- often in the first few minutes of trading. Consider the IPO of Boston Rotisserie Chicken, which has since been renamed Boston Market. The company's underwriter, Merrill Lynch, set an offering price of $\$ 20$ a share. However, because of intensive demand for the issue, the stock's price rose by 143 percent by the end of the first day, and the company's end-of-the-day market value was $\$ 800$ million, which was particularly starling, given that the company reported a $\$ 5$ million loss on only $\$ 8.3$ million of sales at the end of the same year. Similarly, the tre ndy restaurant chain Planet Hollywood which its share rose by 50 percent in the first day of trading, and Ne tscape which its stock's price hit $\$ 70$ a share versus an IPO price of $\$ 28$ a share.

It is important to recognize that firms can go public without raising any additional capital. When the Ford Motor Foundation sold some of its stock to the general public, the Ford Motor Company went public, even though the company raised no capital in the transaction [Brigham 1999 and 2002]. Another important point is that even if you are able to identify a hot issue, it is often difficult to purchase shares in the initial public offering, because investment bankers favor institutional investors (who are their best customers), and small investors find 
it hard to get in on at the initial public offering price. Thus they buy the stock always at the after-market price. Jay R. Rittter (1991) studied this case and found out that, for small investors, the average IPO underperforms the overall market over the long-run.

\section{The Scope and Nature of the Paper}

This paper aim is to discuss Venture Capital (VC) and the process involved in the Initial Public Offerings (IPOs) performances. It introduces the concept and statistics of venture capital, the stages of venture capital funding, and the expectation for such investment from the point of view of the investors. This will set the stage for the introduction of initial public offerings process, along with the preparatory steps involved in the process before an actual IPO distribution. The discussions include the allotment pricing, distribution of IPOs, the risk and effects of flipping, factors affecting IPOs successes, and democratization and client-side participation.

To enhance the discussion, this paper presents three case studies involving three popular IPO performances: eBay, Goldman Sachs, and the United Parcel Service. While these three companies are very different from each other because they offer different products and run different businesses to the general public, they are all an example of a successful IPOs. This study was conducted in the 2001, with an emphasize on the years 1999 and 2000. Bear in mind that in the first half of 2000, a period of supernormal growth in the IPO offerings and a period of abnormal growth in the stock market, we have seen thousands of IPOs with nearly one-half flopped in the fourth quarter of 2000, and most of those remaining declared bankrupt in 2001.

Venture capital process and investment in many new companies are often started at times when there is hype about a particular industry. The investment process helps creation and development of an IPOs. Of course there are many who believe that IPOs motivate and develop venture capitalists, but history indicates otherwise. However, every company has a phase where there is only an idea and a couple of employees with passion about what they do, or it is because there is negative earnings and there is a need for capital for expansion which forces entrepreneurs to seek venture capital funding from angel investors and venture capital investment firms.

\section{Venture Capital Funding}

Venture Capital while it is not a household name, it is a growing investment opportunity. According to The Money Tree Survey, the first nine months of 1999 have seen over \$21 billion of venture capital invested in about 2300 firms, an average of $\$ 9.1$ million invested in each firm. In the second quarter, $\$ 7$ billion and in the third quarter a record setting $\$ 9$ billion was invested in IPOs. Together, these two quarters of 1999 surpass the total amount of VC investments for all of 1998. As shown by the Figure $1 \mathrm{VC}$ investments have been growing steadily with a huge increase in spending this year [Price Waterhouse Cooper Money Tree Report 1999].

Other interesting statistics relating to Venture Capitalists are where they have placed their investments. Recently, the business press documents a change in the economy to a new, so-called "E-conomy" where technology is being utilized like never before. According to the MoneyTree survey, as shown in Table 1, the top funding has been in communications representing 27.8 percent of all VC investments. Additionally, 24.7 percent of $\mathrm{VC}$ funds have been placed in software companies. With so much funding in high tech industries, it stands to reason that investments will be in parts of the country where new firms are based. Since most technology firms are located in Silicon Valley, it is easy to understand why 37 percent of $\mathrm{VC}$ has been allocated to this region. Table 2 shows that New England follows at a distant second with only 10 percent of venture capital funds. Additionally, according to InvestorHome.com, of all new firms that get VC funding, 30 percent will be complete losses and 40 percent will be so called "living dead". The remaining 30 percent of investments offer huge returns-often 10 times or more of the initial investment. 
Figure I: VC Funding Per Quarter

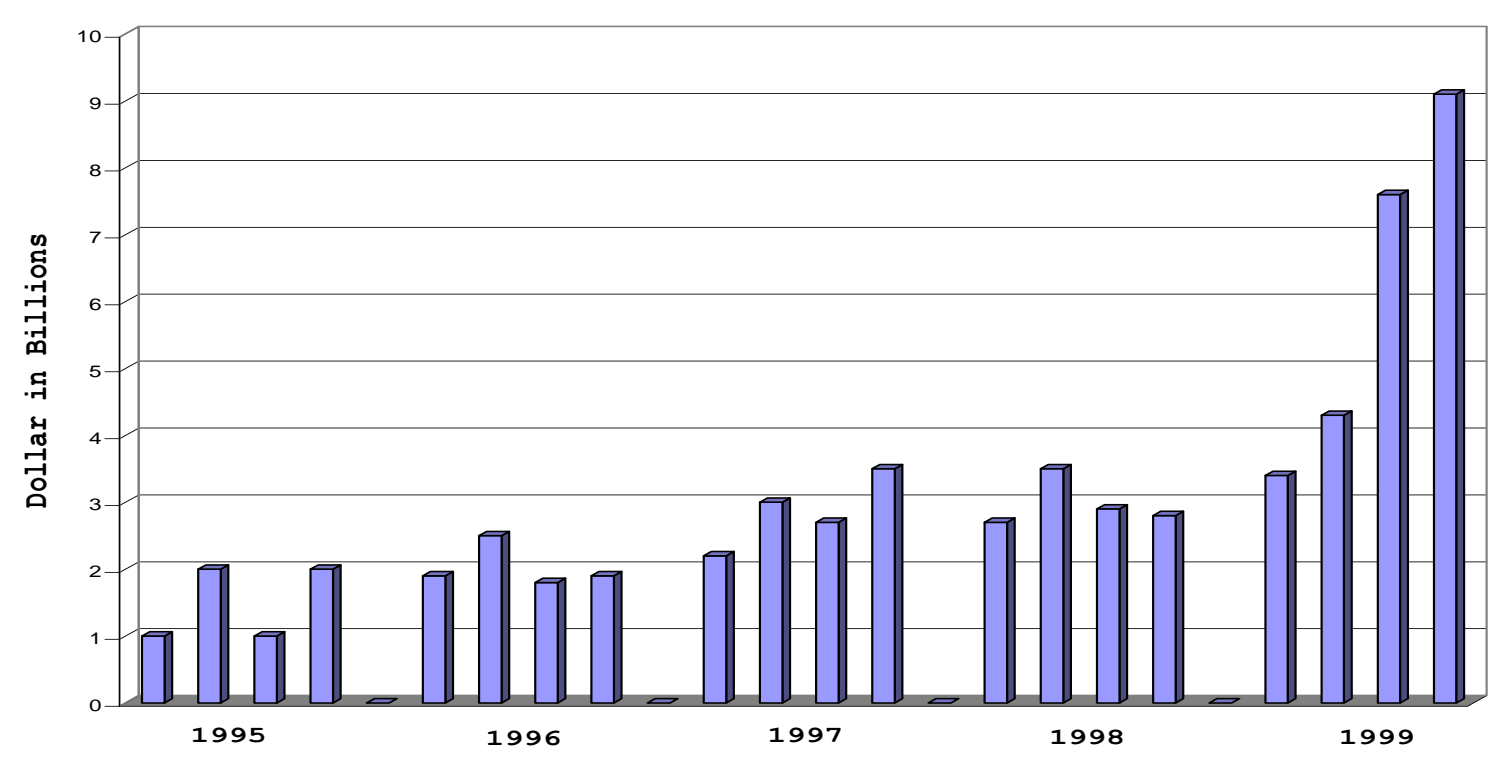

Source: PriceWaterhouseCoopers MoneyTree Report Note: All numbers have been rounded.

Table 1: Major Investment By Industry, 1999-2000 Average per Quarter

\begin{tabular}{|lcclcc|}
\hline Industry & $\begin{array}{c}\text { Average } \\
\text { Investment } \\
\text { (\$billion) }\end{array}$ & \% of Total & Industry & $\begin{array}{c}\text { Average } \\
\text { Investment } \\
\text { (\$billion) }\end{array}$ & \% of Total \\
\hline Communication & 2.7 & 27.8 & Healthcare & 0.5 & 5.2 \\
Software & 2.4 & 24.7 & Biotechnology & 0.4 & 4.1 \\
Business Services & 1.8 & 18.6 & Computers & 0.3 & 3.1 \\
Consumer Products & 0.8 & 8.2 & Medicals & 0.2 & 2.1 \\
Distributions & 0.6 & 6.2 & & & \\
\hline
\end{tabular}

Source: PriceWaterhouseCoopers MoneyTreee Report, 2001.

Note: All numbers have been rounded.

Table 2: Investments By The Major City/Region, 1999-2000 Average Per Quarter (\$Billion)

\begin{tabular}{|llll|}
\hline Silicon Valley & 3.8 & Los Angeles & 0.5 \\
New England & 0.9 & Texas & 0.5 \\
New York & 0.7 & Midwest & 0.3 \\
Washington, D.C. & 0.6 & Colorado & 0.3 \\
Southeast & 0.6 & & \\
\hline
\end{tabular}

Source: PriceWaterhouseCoopers MoneyTreee Report.

Note: All numbers have been rounded. 


\section{Investors' Expectations}

Venture Capitalists are either individuals or firms with excess money who are looking for an investment on the ground floor of a company. Unfortunately, this type of investment is extremely illiquid. The stock that is purchased with VC funding, is not publicly traded. As a result, investors are unable to withdraw their investment until the company is acquired or goes public. With this type or risk, investors tend to be rewarded even more so than an investment of greater liquidity. There is a stereotype that Venture Capitalists will sit down, listen to a business proposal for fifteen minutes, and start to write a check if they actually like the idea. This is far from the fact. These investors do a great deal of research before they commit any funding to a project. The early stages of the investment decision include the Venture Capitalist learning about the new firm and hearing a brief proposal. If the venture capitalist decides the firm requires a closer look, he will start to conduct a detailed analysis of the prospects for the firm. He is interested about the products that will be sold and services that will be providedgenerally qualitative information. He is also very interested in how soon the company may turn profitable, experience of the employees, and prospects for growth in the future. Above all else, the investor is concerned about how much return he will receive on his investment.

The venture capitalist, may find that his previous analysis was inconclusive and will proceed on to the third stage of due diligence. In this stage, the investor may require market studies about how the firm's product might perform. He might also contact third party consultants to inquire of their opinions regarding the investment. Once the investor has decided to invest in the company, he must sit down with the principals of the firm. The principals usually include the president/CEO of the firm and any major management. At this meeting, the principals and the investor work out a number of issues. One issue is certain to be the amount of money to be invested and timing of that investment. More specifically, any investment may be partially debt financing and partially equity financing. Surely, the firm would not want to lose all control by selling only equity. Equally as certain, the investor would not just want to be a lender and not take part of any growth experienced. Additionally, the investor may feel that his expertise would be very valuable to the company and he may want to be consulted on a regular basis [Riding/Orser online]. After the investor funds the company, he may be asked to invest further at another time in additional rounds of financing. Even if he fails to participate in funding again, he will be continually monitoring the progress of his initial investment and make major interventions only as needed.

\section{Stages Of Venture Capital Funding}

There are many stages to the development of a company. As previously described, the investor will carefully consider his actions at every stage of possible investment. Traditionally, the stages from idea to IPO would take place over a period of five to ten years. The situation has been changed and decisions are often made in a very short period of time. New Internet companies have been quite an exception. Frequently, an entrepreneur might have an idea for a company, set up the web page, and have the company go public in less than a year. Despite this, many companies still follow the traditional funding approach, as shown by Figure 2. The first stage of investing is the Seed Financing Stage. During this stage, the company is still mainly an idea. This is the start of a long journey with many times the company could die. However, it is this risk that makes this stage the most profitable to invest in. This is the early stage where the business plan is still being finalized and the company is focusing in on products and services it will offer. The company is planning for its future and considering strategy for growth. Ironically, the second stage is called the First Stage. At this stage, the company uses venture capital to pay employee salaries and other expenses. The employees are mainly concerned with getting a prototype together and making it operational.

The irony continues, as the next stage is the Second Stage. Here, risk has been greatly reduced because a prototype for the product actually exists. The employees are usually working out any technical glitches in the prototype, but some employees have actually been hired to market and sell the product. Venture Capital at this stage is still used to pay salaries and any revenue generated is insignificant. Earnings do not exist in this stage. 
Figure 2: Stages of Venture Capital Investment Exit Stage

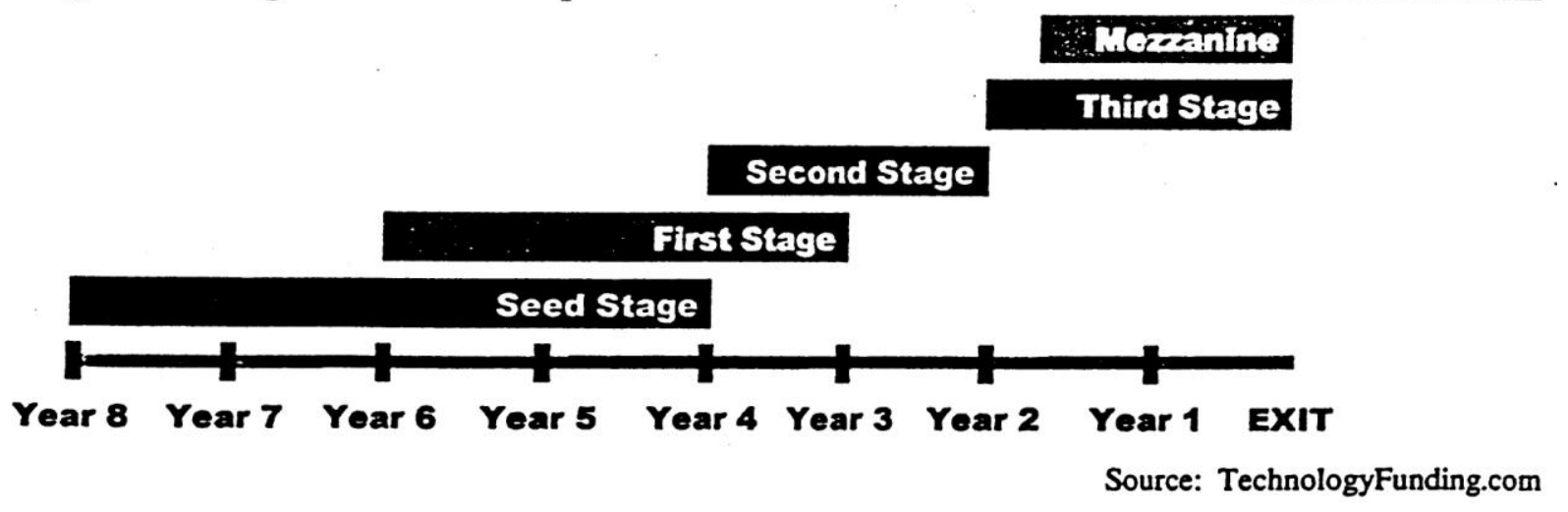

In the Third Stage, the company is now producing its product and generating nominal revenues. Marketing kicks into high gear at this stage and mind share is created. Venture Capital is now generally used for marketing activities and other areas of growth. In the Mezzanine Stage, venture capitalists invest for the last time. Funds are primarily used for further expansion and trying to reach for profitability. It is at this stage that the company may consider going public in an IPO. Earnings may exist, but the company is still spending a great deal of money on expanding the firm. The final stage is the Exit Stage. The company has either gone public or has been targeted as an acquisition by another company. At this stage, there is no risk remaining and they are just awaiting a paycheck. The company has definitely grown and they will profit as they sell their stake in the company.

\section{The IPO Process}

Going public means selling some of a company's stock to outside investors and then let the stock trade in public markets. This is an individual decision that should be made on the basis of the company's and stockholders' own unique circumstances. There are several advantages and disadvantagres of going public. The advantages are: permits founders to diversify, increases liquidity, facilitates raising new corporate cash, and establishes a value for the firm. The disadvantages are: increase the cost of quarterly and annual reporting with the SEC, disclosure of operating data, maintaining control over firm and stock trading, and keeping good public relation with investors. Tables 3 and 4 present the initial public stock offering for the years 1999 and 2000. It includes the biggest issuer, the best performers, and the worst performers. Table 5 presents the highest first-day IPO returns in 2000 , and Table 6 presents the leading underwriters for initial public offering in 2000.

Leading Underwriters: After a company decides to go public, it faces the problem of how to sell its stock to a larger number of investors. To help in this process, the company select an investment banks, also called underwriters, to help the film to determine the preliminary offering price, or price range, for the stock and the number of shares to be sold. In 2000, the ten leading underwriters offered 344 IPOs, with a value of \$159.4 billion. Most of the IPOs issued in 2000 were from January to September. In the fourth quarter of 2000, economy starts to turn downward and stock market reacted negatively to the high inventories and low revenue and profits of corporations. The technology stocks and IPOs, the backbone of the economic growth of 1993 to 1999 , were hit hard, causing speculation for an economic recession. Overall, in the year 2000, the IPOs activities were near 22 percent below 1999. The leading underwriter, Goldman, Sacks \&Company issued 60 IPOs, for an amount of $\$ 40$ billion, or approximately 25 percent of the ten leading underwriters in 2000.

\section{Initial Steps Before The IPO And Procedures}

There are several things that companies must do in preparation before they even decide to go public in the market. Companies may begin plans for a public offering as much as two years in advance, by preparing detailed financial information concerning the benefits and problems associated with an IPO. This ascertains the amount of equity that is actually required for expansion of the business and capital expenditures for new projects. Additional 
factors the company must consider when making their plans include: how soon the capital is required, the best time of year for strong demand in the IPO market, and they must also identify the target group of people that they want their offering to appeal to.

The timeline of events associated with an IPO consists of three steps. After the company has decided that an IPO might be beneficial, a lead underwriter (Lead Manager) is chosen to manage the complexities of the issue. Generally, a lawyer and an accountant are included in the IPO team, along with the investment bank, to assist with the offering. In the initial stages, the company consults with the IPO team in order to consider other aspects that they may not have contemplated previously. Once the company has decided that it will go through with an IPO, the process officially begins with an "all-.hands" meeting. This meeting usually takes place six to eight weeks before the company officially registers with the Securities and Exchange Commission. Together, the IPO team plans a schedule for the events required for going public and assigns certain duties to each member. From this point, the team develops a prospectus, which is basically a brochure trying to sell the company. The prospectus is very valuable to the company because after a company has submitted a request to the SEC to go public there is a "quiet period" that lasts for approximately twenty-five days after the stock begins trading. Therefore, the prospectus must be the full representation of the company, its products, its competitors, and what it's objective is to the consumer. The prospectus also contains valuable financial information from the past five years that will assist investors and others in learning more about the stability of the company and its financial position.

The second step is associated with filing with SEC and incorporating SEC's revisions. Additional underwriters will be invited to join in and C0-Lead Managers will be selected to organize the administrative body and middle managements. SEC review normally takes 20 days. The final stage is devoted to the pricing of the IPOs and selection of agents for distribution.

According to Louis Corrigan, evidence shows that during a bull market initial public offerings flourish. As shown in Figure 3, area A, the market declined significantly during such period. All three major indices are in correction territory having declined by more than 10 percent. The IPO market has reacted to the broader market, and the number of companies going public at this time has dropped off. In area B, the market is experiencing a very steady rally. The market is very bullish and the number of new monthly issues is rising in step with the broader market. Interestingly, in area $\mathrm{C}$, the markets dips below their highs, but very quickly rise back to their previous levels. The tech-heavy NASDAQ, comprised of many new issues, suffers the worst decline. The correlation between the decline of NASDAQ issues with new IPOs is especially interesting. As with the preceding examples, the number of IPOs per month drops lower in sympathy with the broader markets. However, as the markets rebound, so do the number of IPOs that are issued per year.

\section{Risk And Effect Of Flipping}

The IPO market is not a place where one is guaranteed to get rich quick. IPOs generally have a tremendous run-up on the first day of trading. However, if the stock does go up, the only people who profit are those who get shares allocated to them by the underwriter. In fact, after the first day of trading, the average annual return on an IPO is less than two percent for the first year. Historically, it is 2 percent is less than the inflation rate. Therefore, the average person would be financially much better off to put their money into an interest bearing savings account rather than to invest in an IPO. Another important point to note is that there are problems associated with investors who are looking to receive shares from the underwriter, only to sell them at a very high price on the first day of trading. In fact, investment firms frown upon this idea of "flipping" IPOs. While it is not illegal to flip the stocks in order to earn a high profit, the investor is merely cutting his own throat because chances are the investment firm will not include him on future offerings [Chang 1999]. Most firms request that their clients hold any shares they received from an offering for at least a month or two; some may require even more time. Wit Capital is so serious about it's clients not flipping, that it requests a sixty-day holding period, with a 5\% penalty if the stock is sold early [Frick 1998]. The investment firm is in part looking out for it's own self-interest. If a significant number of its clients flip the stock, then it endangers the underwriter's opportunity of future commissions and offerings by other companies that wish to go public. Therefore, if 'getting rich quick is on the mind of an investor, chances are that an underwriter will not allow the investor to participate. To demonstrate the problems associated with flipping more specifically, we have continued our previous economic discussion. 
Table 3: Initial Public Stock Offering, 1999

\begin{tabular}{|c|c|c|c|c|c|}
\hline ISSUER & $\begin{array}{c}\text { OFFERING } \\
\text { DATE }\end{array}$ & $\begin{array}{l}\text { OFFERING } \\
\text { PRICE }\end{array}$ & $\begin{array}{c}\text { U.S. } \\
\text { PROCEEDS } \\
\text { (Millions) } \\
\end{array}$ & \multicolumn{2}{|c|}{$\begin{array}{c}\text { PERCENT CHANGE } \\
\text { FROM OFFER DATE } \\
\text { TO } 12 / 31 / 99\end{array}$} \\
\hline \multicolumn{6}{|l|}{ THE BIGGEST } \\
\hline United Parcel Service & $11 / 9 / 99$ & $\$ 50.00$ & $\$ 4,376.0$ & \multicolumn{2}{|c|}{$+38.0 \%$} \\
\hline Goldman Sachs Group & 5/3/99 & 53.00 & $2,925.6$ & \multicolumn{2}{|c|}{+77.7} \\
\hline Charter Communications & $11 / 8 / 99$ & 19.00 & $2,745.5$ & \multicolumn{2}{|c|}{+15.2} \\
\hline Pepsi Bottling Group & $3 / 30 / 99$ & 23.00 & $1,955.0$ & \multicolumn{2}{|c|}{-28.0} \\
\hline Genentech & $7 / 20 / 99$ & -97.00 & $1,940.0$ & \multicolumn{2}{|c|}{+177.3} \\
\hline Agilent Technologies & $11 / 17 / 99$ & 30.00 & $1,818.0$ & \multicolumn{2}{|c|}{+157.7} \\
\hline Sonera Group (Finland) & $10 / 12 / 99$ & 25.60 & $1,725.9$ & \multicolumn{2}{|c|}{+170.5} \\
\hline Delphi Automotive Systems & 2/4/99 & 17.00 & $1,445.0$ & \multicolumn{2}{|c|}{-7.4} \\
\hline Epcos (Germany) & $10 / 14 / 99$ & 33.34 & $1,212.4$ & \multicolumn{2}{|c|}{+123.5} \\
\hline Enel Societa per Azioni (Italy) & $11 / 1 / 99$ & 45.23 & $1,108.1$ & \multicolumn{2}{|c|}{-8.8} \\
\hline \multirow[t]{2}{*}{ ISSUER } & \multirow{2}{*}{$\begin{array}{l}\text { OFFERING } \\
\text { DATE }\end{array}$} & \multirow{2}{*}{$\begin{array}{l}\text { OFFERING } \\
\text { PRICE }\end{array}$} & \multirow{2}{*}{$\begin{array}{c}\text { U.S. } \\
\text { PROCEEDS } \\
\text { (Millions) } \\
\end{array}$} & \multicolumn{2}{|c|}{$\begin{array}{l}\text { PERCENT CHANGE } \\
\text { FROM OFFER DATE }\end{array}$} \\
\hline & & & & FIRST DAY & $12 / 31 / 99$ \\
\hline \multicolumn{6}{|l|}{ THE BEST PERFORMERS } \\
\hline Internet Capital Group & $8 / 4 / 99$ & $\$ 12.00$ & $\$ 143.0$ & $+103.7 \%$ & $+5,567.0 \%$ \\
\hline Commerce One & 7/1/99 & 21.00 & 69.3 & +190.5 & $+2,707.1$ \\
\hline Purchasepro.com & 9/13/99 & 12.00 & 48.0 & +117.7 & $+2,479.7$ \\
\hline VerticalNet & 2/10/99 & 16.00 & 56.0 & +183.6 & $+1,950.0$ \\
\hline Brocade Comm. Systems & $5 / 24 / 99$ & 19.00 & 138.2 & +138.2 & $+1,763.2$ \\
\hline Vignette & $2 / 18 / 99$ & 19.00 & 76.0 & +124.7 & $+1,615.8$ \\
\hline Liberate Technologies & $7 / 27 / 99$ & 16.00 & 100.0 & +26.6 & $+1,506.3$ \\
\hline RedbackNetworks & $5 / 17 / 99$ & 23.00 & 57.5 & +296.6 & $+1,443.5$ \\
\hline Ariba & $6 / 22 / 99$ & 23.00 & 115.0 & +291.3 & $+1,442.4$ \\
\hline Red Hat & $8 / 11 / 99$ & 14.00 & 84.0 & +271.4 & $+1,408.9$ \\
\hline \multirow[t]{2}{*}{ ISSUER } & \multirow{2}{*}{$\begin{array}{c}\text { OFFERING } \\
\text { DATE }\end{array}$} & \multirow{2}{*}{$\begin{array}{c}\text { OFFERING } \\
\text { PRICE }\end{array}$} & \multirow{2}{*}{$\begin{array}{c}\text { U.S. } \\
\text { PROCEEDS } \\
\text { (Millions) }\end{array}$} & \multicolumn{2}{|c|}{$\begin{array}{l}\text { PERCENT CHANGE } \\
\text { FROM OFFER DATE }\end{array}$} \\
\hline & & & & FIRST DAY & $12 / 31 / 99$ \\
\hline \multicolumn{6}{|c|}{ THE WORST PERFORMERS } \\
\hline Value America & 4/8/99 & $\$ 23.00$ & $\$ 126.5$ & $+140.0 \%$ & $-78.0 \%$ \\
\hline Insurance Mgmt Solutions & $2 / 11 / 99$ & 11.00 & 36.9 & Unch. & -77.3 \\
\hline Statia Terminals & $4 / 23 / 99$ & 20.00 & 152.0 & -8.1 & -73.1 \\
\hline Trion Technology & $6 / 4 / 99$ & 7.00 & 8.4 & +22.3 & -69.6 \\
\hline Argosy Education & 3/8/99 & 14.00 & 28.0 & -4.0 & -68.3 \\
\hline Fashionmall.com & $5 / 21 / 99$ & 13.00 & 39.0 & Unch. & -65.9 \\
\hline Skechers USA & 6/9/99 & 11.00 & 77.0 & -3.4 & -65.4 \\
\hline FlashNet Communications & $3 / 16 / 99$ & 17.00 & 51.0 & +156.6 & -63.6 \\
\hline HI-Q Wason & $9 / 21 / 99$ & 7.00 & 7.7 & -4.4 & -62.4 \\
\hline Packaged Ice & $1 / 29 / 99$ & 8.50 & 91.4 & -2.9 & -61.8 \\
\hline
\end{tabular}


Table 4: Initial Public Sock Offering, 2000

\begin{tabular}{|c|c|c|c|c|c|}
\hline \multirow[t]{2}{*}{ ISSUER } & \multirow{2}{*}{$\begin{array}{c}\text { OFFERING } \\
\text { DATE }\end{array}$} & \multirow{2}{*}{$\begin{array}{c}\text { OFFERING } \\
\text { PRICE }\end{array}$} & \multirow{2}{*}{$\begin{array}{c}\text { U.S. } \\
\text { PROCEEDS } \\
\text { (Millions) }\end{array}$} & \multicolumn{2}{|c|}{$\begin{array}{c}\text { PERCENT CHANGE FROM } \\
\text { OFFER }\end{array}$} \\
\hline & & & & FIRST DAY & $12 / 31 / 2000$ \\
\hline \multicolumn{6}{|l|}{ The Best Performers } \\
\hline Embarcadero Technologies & April 20 & $\$ 10.00$ & $\$ 42.0$ & $+60.0 \%$ & $+350.0 \%$ \\
\hline Krispy Kreme Doughnuts & April 5 & 21.00 & 63.0 & +82.7 & +295.2 \\
\hline First Horizon Pharmaceutical & May 31 & 8.00 & 30.4 & +3.1 & +284.4 \\
\hline Sonus Networks & May 25 & 7.67 & 115.0 & +119.6 & +229.3 \\
\hline Sun Life Finl Svcs of Canada & March 23 & -8.50 & 305.2 & +10.3 & +213.2 \\
\hline Stanford Microdevices & May 25 & 12.00 & 48.0 & +28.1 & +200.0 \\
\hline Praecis Pharmaceuticals & April 27 & 10.00 & 80.0 & +10.0 & +192.5 \\
\hline Ulticom & April 5 & 13.00 & 55.3 & +53.9 & +171.2 \\
\hline Community Health Systems & June 9 & 13.00 & 243.8 & +5.3 & +169.2 \\
\hline webMethods & Feb. 11 & 35.00 & 165.0 & +507.5 & +167.0 \\
\hline \multicolumn{6}{|l|}{ The Worst Performers } \\
\hline Pets.com & Feb.11 & $-\$ 11.00$ & $\$ 66.0$ & $-34.1 \%$ & $-99.1 \%$ \\
\hline HealthGate Data & Jan. 26 & 11.00 & 41.3 & +6.8 & -98.3 \\
\hline Varsity Books.com & Feb. 15 & 10.00 & 40.8 & -1.3 & -98.1 \\
\hline ImproveNet & March 16 & 16.00 & 44.2 & -11.7 & -97.7 \\
\hline Asiacontent.com & April 12 & 14.00 & 70.0 & -21.4 & -97.3 \\
\hline Uproar & March 17 & 33.88 & 84.7 & -21.0 & -97.1 \\
\hline Netpliance & March 17 & 18.00 & 144.0 & +22.6 & -97.1 \\
\hline Opus360 & April 7 & 10.00 & 77.0 & +25.0 & -96.9 \\
\hline Savvis Communications & Feb. 15 & 24.00 & 408.0 & +0.0 & -96.4 \\
\hline BusyBox.com & June 28 & 5.00 & 12.5 & +11.3 & -96.2 \\
\hline
\end{tabular}

Source: $\quad$ Kara Scanell, "IPO Rocket Lands as Investors Prefer Profits to Pipe Dreams", The Wall Street Journal, January 2, 2001, R6; and Brigham 2002.

Table 5: Highest First-Day IPO Returns In 2000

\begin{tabular}{|clrcrrrr|}
\hline \multirow{2}{*}{ RANK COMPANY (SYMBOL) } & $\begin{array}{c}\text { OFFER } \\
\text { DATE }\end{array}$ & $\begin{array}{c}\text { SHARES } \\
\text { (In Millions) }\end{array}$ & $\begin{array}{c}\text { OFFERING } \\
\text { PRICE }\end{array}$ & $\begin{array}{c}\text { FIRST DAY } \\
\text { CLOSING } \\
\text { PRICE }\end{array}$ & GAIN/LOSS & $\begin{array}{c}\text { 12/29/00 } \\
\text { CLOSE }\end{array}$ \\
\hline 1 & webMethods (WEBM) & $2 / 10 / 00$ & 4.10 & $\$ 35.00$ & $\$ 212.63$ & $507.51 \%$ & $\$ 88.94$ \\
2 & Crayfish (CRFH) & $3 / 6 / 00$ & 4.35 & 24.50 & 126.00 & 414.28 & 8.75 \\
3 & Avanex Corporation (AVNX) & $2 / 3 / 00$ & 6.00 & 36.00 & 172.00 & 377.77 & 59.56 \\
4 & Selectica (SLTC) & $3 / 9 / 00$ & 4.00 & 30.00 & 141.23 & 370.76 & 24.19 \\
5 & FirePond (FIRE) & $2 / 3 / 00$ & 5.00 & 22.00 & 100.25 & 355.68 & 9.44 \\
6 & AsiaInfo Holdings (ASIA) & $3 / 2 / 00$ & 5.00 & 24.00 & 99.56 & 314.83 & 9.38 \\
7 & Neofornia.com (NEOF) & $1 / 24 / 00$ & 7.00 & 13.00 & 52.38 & 302.92 & 0.81 \\
8 & Versata (VATA) & $3 / 2 / 00$ & 3.85 & 24.00 & 92.75 & 286.45 & 8.94 \\
9 & UTStarcom (UTSI) & $3 / 2 / 00$ & 10.00 & 18.00 & 68.88 & 282.66 & 15.50 \\
10 & Marvell Technology Group (MRVL) & $6 / 26 / 00$ & 6.00 & 15.00 & 56.63 & 277.53 & 21.94 \\
\hline
\end{tabular}

Source: http://www.ipo.com and Brigham 2002

Note: Offer price is adjusted to reflect stock splits 10 
Table 6: Leading Underwriters For Initial Public Offerings, 2000

\begin{tabular}{|c|c|c|c|c|}
\hline RANK & UNDERWRITER & $\begin{array}{l}\text { NUMBER OF } \\
\text { IPO's }\end{array}$ & $\begin{array}{l}\text { VALUE OF DEALS } \\
\text { (In Billions) }\end{array}$ & $\begin{array}{l}\text { AVERAGE RETURN } \\
\text { DURING YEAR }\end{array}$ \\
\hline 1 & Goldman, Sachs \& Co. & 60 & $\mathrm{~S} 40.1$ & $-13.91 \%$ \\
\hline 2 & Morgan Stanley Dean Witter & 52 & 27.5 & -21.76 \\
\hline 3 & Merrill Lynch \& Co. & 40 & 25.4 & 1.15 \\
\hline 4 & Salomon Smith Barnet & 33 & 22.1 & -12.70 \\
\hline 5 & Credit Suisse First Boston & 65 & 14.5 & -13.59 \\
\hline 6 & Deutsche Banc Alex. Brown & 32 & 8.5 & 0.99 \\
\hline 7 & China International Capital Corp. & 3 & 8.4 & -44.65 \\
\hline 8 & ABN AMRO Rothschild & 3 & 4.7 & 13.46 \\
\hline 9 & Donaldson, Lufkin \& Jenrette & 23 & 4.2 & -7.11 \\
\hline 10 & Lehman Brothers & 33 & 4.0 & -20.79 \\
\hline
\end{tabular}

Note: $\quad$ Excludes units, closed-end funds, and deals priced below $\$ 5$.

Table 7 Timeline Of Events Associated With An IPO

\begin{tabular}{|c|c|c|c|c|c|}
\hline & Creation of Prospectus & & SEC Review & & Going Public and Distribution \\
\hline * & Information gathering & $*$ & $\begin{array}{l}\text { Filing with SEC and } \\
\text { review of prospectus }\end{array}$ & * & $\begin{array}{l}\text { Executives of IPO company } \\
\text { meet with underwriters to } \\
\text { determine final price per share }\end{array}$ \\
\hline$*$ & Choose leading underwriter & $*$ & $\begin{array}{l}\text { SEC review completed } \\
\text { (>20 days before IPO) }\end{array}$ & $*$ & Distribution stage started \\
\hline$*$ & IPO team formed & $*$ & $\begin{array}{l}\text { SEC revisions incorporated } \\
\text { into final prospectus }\end{array}$ & & \\
\hline
\end{tabular}

Figure 3: Correlation Between Market Strength And IPOs Offering

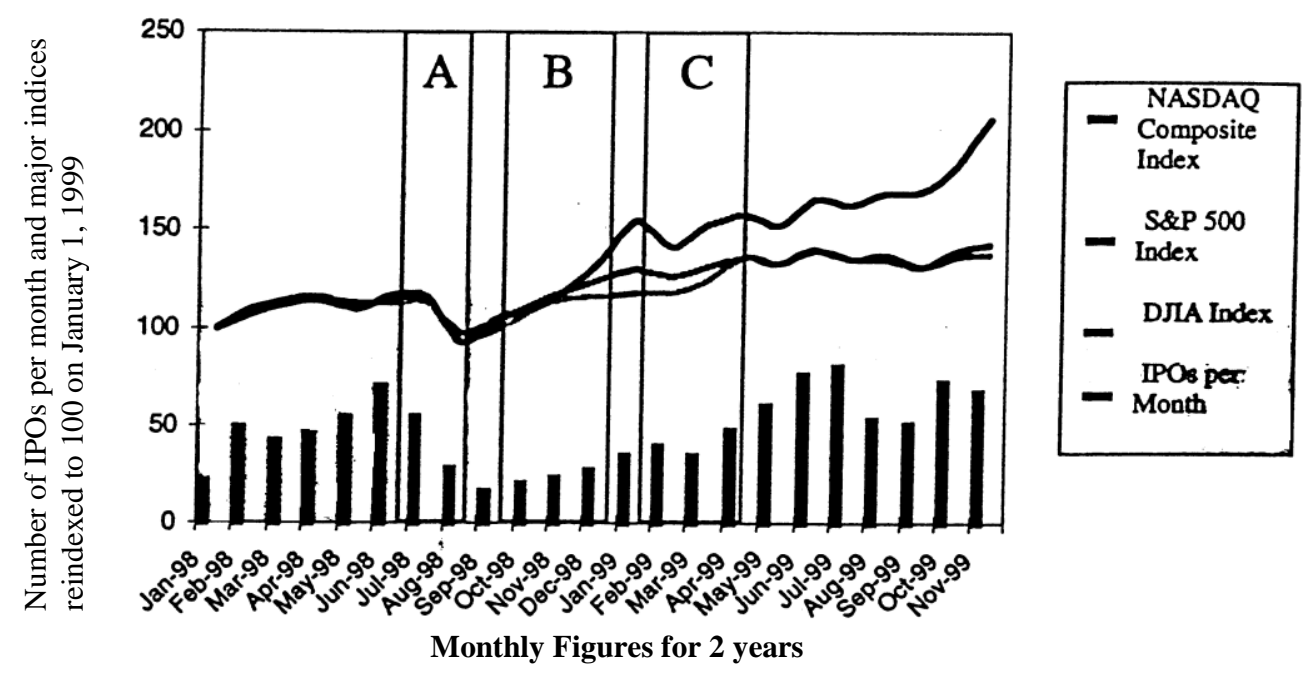

\section{Democratization And Client-Side Participation}

There are average investors, who may not meet the "preferred client" definition that are interested in participating in initial public offerings. Before, the idea of any commoner participating in an IPO was unfathomable. However, the explosion of Internet services, online brokerage firms, and easy access to the masses 
has enabled this dream to become a reality. Companies such as Wit Capital and $\mathrm{E}^{*}$ OFFERING are opening the doors to use the Internet as a vital distribution tool in the IPO market. At first, it may seem like the process that these two companies follow is not drastically different from the traditional process. This is far from the case. Although they do follow a similar timeline; the availability of participation is widespread to clients. Clients do not need to have $\$ 500,000$ in assets with their brokerage; rather, people may participate with as little as $\$ 1,000$ [TECHcapital online]. This $\$ 1,000$ minimum amount used to be insufficient for even a brokerage account, but it now allows people access to the world of online trading with smaller commissions. As people go online for regular market trading, they are able to go to special areas of the web site to find if there are any offerings available. As investors discover what offerings exist, they find out when they are tentatively going to go public. Investors can fill out a form online that lets their brokerage firm know that they are interested in participating in the IPO.

Brokerage/underwriters like Wit Capital and E*OFFERING, are then able to take whatever shares they have been allocated from the syndication and distribute them on a first come, first served basis to their clients that meet the criteria for participation. These criteria may include a history free of flipping, maintaining the minimum balance in one's account, or having a certain risk tolerance with regard to one's investment strategy. Another company, Hambrecht \& Quist, has taken an alternate way of proposing initial public offerings by auctioning shares over the Internet, in a "Dutch Auction." A Dutch auction operates in a manner where investors participate by making a bid per share for what they believe the company is worth, whether it is below, above, or within the estimated pricing range. All of the bids submitted are sealed. By operating in this manner, the final IPO price is a representation for what investors are truly willing to pay for the stock. Bids may be changed or withdrawn up until the close of the auction. Upon closure of the auction, the firm will set a single offering price based on the bids received at which all the shares can be sold. Those investors who bid lower than the set price will not be able to purchase any of the shares [Business 2.0, online].

These new methods of distribution are not widespread. They are merely a foot in the financial doorway allowing more people access to a smoke filled room. While there are still some quirks to be worked out with the new ways of investing in IPOs there is still a sense of accomplishment to the average investor. Participation in the process, no matter how small monetarily still gives a thrill when investors see press coverage about a stock that they purchased. As the Internet becomes more prevalent in society and more stock trading occurs online, more people will participate in IPOs and an increasing number of companies will opt for this means of financing. Historical Perspective of IP0 Performance The recent success of Initial Public Offerings is an interesting chapter in the history of the stock market. The craze for new issues is not an entirely new phenomenon. According to Burton Malkiel, author of A Random Walk Down Wall Street, between 1959 and 1962, more new issues were entered the market than in any previous period. A myriad of companies went public and regardless of their association with electronics, played into the hype of the time and used corporate names indicative of work in the ele ctronics industry. At the time, new electronic devices were being created and gobbled up by consumers. In response to the public embrace of the new technology, investors raced for their checkbooks. Investors clamored to buy any new stocks whose name suggested work in technology industries. After several periods of soaring prices, the high price of the "tronics boom" fell back into check.

History decided to repeat itself in the first half of 1983 when another technology boom occurred. This time, the craze was for biotechnology and microelectronics. The total flotation of new public offerings in 1983 reached $\$ 15$ billion, four times the record set in 1981, and more than the total amount raised for new issues in the prior decade. Malkiel notes, "Just getting a piece of a new issue automatically made you a winner... prices often soared in' the after market." Our culture relies on technology for continuous improvements of our lifestyles and environment. The market greatly rewards the companies who hold the keys to this future. With this historic perspective, it is not hard to believe that the past is repeating itself again. In August 1995, a small little company called Netscape Communications went public and its stock went through the roof. This IPO brought the Internet into the consciousness of mainstream investors. Ever since, Internet IPOs have performed extraordinarily well with the plethora of "dot.coms" clearly reminding of the "tronics" companies of earlier years. 


\section{Effects Of Increased Trading}

Several other factors played key roles into the recent performance of Initial Public Offerings. One aspect is that many investors are attracted to the glamour related to an IPO. IPO investors dream that they have just bought the next Microsoft and will be able retire from work only to watch the value of their portfolios soar. They watch CNBC coverage of their IPO and know that Maria Bartiromo is talking about something with which they were involved. The dream shared by many causes IPOs to be oversubscribed, meaning that more people request the right to purchase the stock than are actually available. Over-subscription feeds the demand fire driving prices up in the secondary market. Investors, who missed out, still hope to catch the stock early on.

Additionally, day traders significantly impact IPO successes by creating self-fulfilling prophecies about stock prices. The development of the Internet essentially created this new field of investing. First, the creation of online investing services has driven down the cost of trades, drawing in record numbers of investors. Second, investors have instant access to massive amounts of information about companies and stock performance online. This ease of access is unprecedented in the investment community. Into this environment, the day trader' enters. Day traders' activities also contribute to the Initial Public Offering mania. Day traders bring liquidity and volume to the market, holding their investments for a matter of minutes before selling again. The foundation of day trading bases upon the trader's belief the stock's value will rise. People believe the stock will go up, and react by buying, or harbor hopes for the stock's future and buy. This phenomenon creates a self-fulfilling prophecy. The desires of investors to purchase a stock they believe will rise, causes others to react and drive up the prices. This partially explains the recent surge in prices of IPOs. Conformity to group actions is an aspect of human nature that carries the stock market to stratospheric valuations.

\section{Case Studies}

Over the past few years, Initial Public Offerings have grown tremendously. IPOs have financed the new economy and enabled greater amounts of financing for individuals and corporations. There are several companies which particularly standout in the economy as IPOs. We chose to discussion three best known.

\subsection{Case I: eBay, Inc.}

eBay is the world's largest and most popular trading community between individual people on the Internet. eBay brings buyers and sellers together in an on-line auction forum where they may freely buy and sell personal items such as coins, collectibles, computers, memorabilia, and toys. This Internet service is available 24 hours a day, seven days a week. Individuals using the eBay web site do not necessarily have to be buyers and sellers. Frequently, people will just meet in an eBay chat room to share information about various items. While searching the eBay web site, they can just get to know others eBay users and have fun at the same time. eBay is currently a growing and successful IPO. eBay, Inc.'s common stock is listed on the NASDAQ National Market and had a 3 for I stock-split on March 2, 1999 (Yahoo Finance 1999).

eBay went public on September 24, 1998. It was brought to market by a syndicate of underwriters including Goldman Sachs as the lead underwriter and other companies such as Donaldson, Lufkin, and Jenrette Securities Corp., Banc Boston Robertson Stephens Inc., and BT Alex Brown Inc. Initially, 3.5 million were sold at first at $\$ 18$ per share. The gross proceeds were $\$ 72.5$ million, where $\$ 5$.I million was applied to the underwriting discount. The remaining $\$ 67.4$ million is the considered to be wealth created for eBay. Ind ividuals and syndicates have profited handsomely as a result of the risk they embraced. As shown by Figure 4, eBay has had an impressive run. eBay went public at a split adjusted price of $\$ 6$ a share. On December 8 , I999, eBay's closing price was $\$ 162$ a share. This is a 2600 percent gain that gives eBay a market capitalization is $\$ 22.9$ billion. When subtracting the IPO funding, one ascertains that the wealth created for investors is $\$ 22.8$ billion in aggregate [eBay1998, Yahoo Finance 1999 and 2000]. EBay is currently trading at \$105. 
Figure 4: eBay Stock Performance

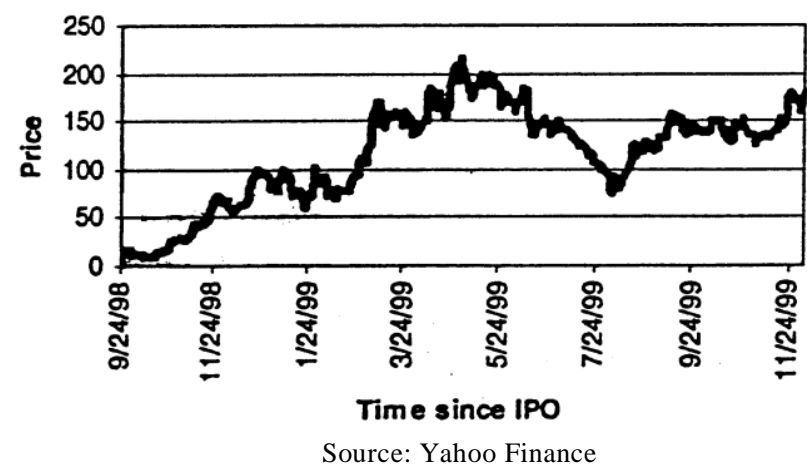

Figure 5: Goldman, Sachs Stock Performance

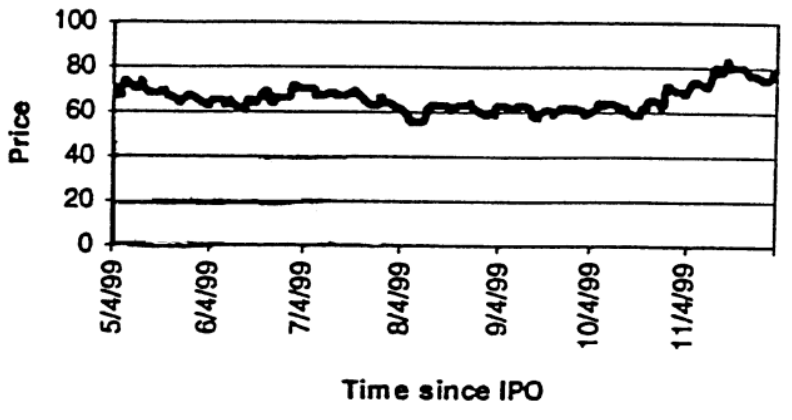

Source: Yahoo Finance

\subsection{Case II• Goldman Sachs, Inc.}

Another recent Initial Public Offering is Goldman Sachs' IPO. For the past few years, IPOs have generally been for new, mostly Internet-related companies. Goldman Sachs changed this preconception on May 7, 1999 when they went public and traded their shares on the New York Stock Exchange for the first time. Goldman Sachs was established over 130 years ago, in the 1860's, as an investment company. The company made a large jump on the first day of trading, reaching a high of $\$ 77$ and closing at $\$ 70$. By May 14, 1999, this IPO was at $\$ 741 / 8$ - a 6 percent gain from the initial closing price. Goldman Sachs' IPO is not like typical IPO. One reason is that Goldman Sachs actually has earnings, unlike most Internet based companies. Investors were very excited about Goldman Sachs' IPO and these investors ordered 600 million shares. However, with only 60 million shares were issued, this stock proved to be drastically oversubscribed. Goldman Sachs is well known in the financial world and investors are hoping that it will continue to be so. This will help to reduce the risk involved with this stock as compared to the riskiness of Internet IPOs [Goldman Sachs 1999]. The syndicate for Goldman Sachs included themselves as the lead underwriter and other companies such as Salomon Smith Barney, Morgan Stanley Dean Witter, and Merrill Lynch \& Co. They issued 55.2 million shares in the US and Canada, 4.6 million shares in the Asia-Pacific region, and 9.2 million shares to the rest of the world. Shares were priced at $\$ 53$, with gross proceeds being $\$ 3.7$ billion. From the total, $\$ 155$ million was applied to the underwriting discounts, resulting in $\$ 2.5$ billion in net proceeds to Goldman Sachs and \$913 million to the partners. Goldman's market capitalization is $\$ 35.1$ billion On December 8, 1999, Goldman Sachs' closing price was $\$ 80$ a share. Compared to the price at which it went public, $\$ 53$ a share, Goldman Sachs has gone up 51 percent in a matter of months. That is an extremely impressive figure for any financial company. Those who were lucky enough to get in on the IPO profited handsomely. However, those who were not allocated shares and bought on the secondary market have not been nearly as successful. If these investors had bought this stock at the closing price of the first day, they would have made 14 percent. This is still somewhat impressive, but not spectacular. According to Figure 10, ever since the IPO, when there was a huge run-up, it has essentially just stayed in a trading range, between $\$ 60$ and $\$ 80$ a share. However, it is currently traded at $\$ 89$.

\subsection{Case III: United Parcel Service, Inc.}

The last well known company, which has gone public in 1999, is the United Parcel Service. UPS is the world's largest package delivery company. This company went public the week of November 21, 1999. The UPS IPO was used to help the company with significant acquisitions in areas of logistics, distribution, and e-commerce. FDX Corp, the parent company of Federal Express has benefited from it's e-commerce involvement. The syndicate for United Postal Service included Morgan Stanley Dean Witter as the lead underwriter and other companies such as Goldman Sachs, Merrill Lynch \& Co., and Salomon Smith Barney. The IPO consisted of 109 million shares sold at $\$ 50$ per share. The gross proceeds to UPS were $\$ 5.5$ billion, where $\$ 191$ million of that figure represented the underwriting discount. UPS currently has a market capitalization of $\$ 79.9$ billion [Yahoo Finance 1999 and 2000, UPS Prospectus for IPO 1999, UPS 10-Q Financial 1999]. 
UPS, share went public at $\$ 50$ a share. The first day of trading, it went up to around $\$ 70$. This represents a 40 percent return for those investors who participated in the IPO. Assuming that certain individuals received shares in the secondary market, there has been little if any return or loss for any investors. Since the IPO, UPS has traded in a very narrow range usually between $\$ 62$ and $\$ 71$.

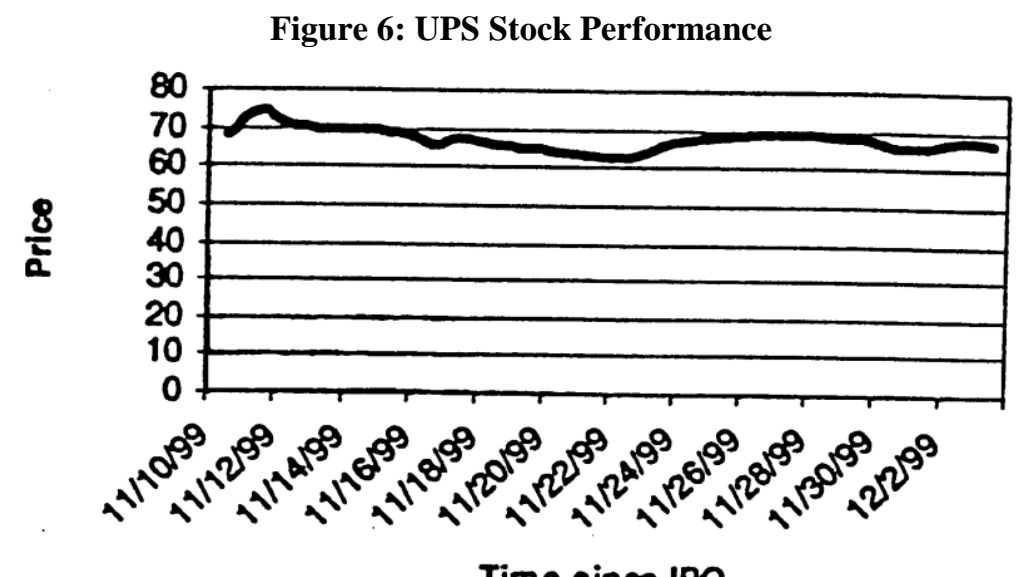

Time since IPO

Source: Yahoo Finance

\section{Conclusion}

The purpose of the analysis of initial public offerings has been to develop a better understanding of the IPOs process. Since the beginning of time, there has always been a certain process whereby entrepreneurs have an idea for a new business and obtain funding for it. The process begins with a search for funding. In many situations, the funding comes through venture capitalists. The venture capitalists seek these opportunities as investments for themselves. As the company prospers, it seeks increased funding by selling equity stakes in itself to the general public. In order for the IPO to be a success, the company must market itself to interested investors. The company is then traded on a stock exchange like many other companies. As technology changes, the means by which these goals are accomplished will surely change. However, the basics will always exist in some way or another.

\section{References}

1. "Beginner's Guide to IPOs", Online: www.hoover's.com.

2. Brigham, Eugene F., Daves, Phillip R., Intermediate Financial Management, Sixth and Seventh Editions, Southwest Publishing, 1999 and 2002.

3. Chang, Yi-Hsin, "How To Get In On An IPO”, March 16, 1999, Online: www.fool.com.

4. Chang, Yi-Hsin, "Unconventional IPOs”, March 16, 1999, Online: www.fool.com.

5. Corrigan, Louis, "Why Stock Offerings Should Make You Nervous", April 11, 1997, Online: www.fool.com.

6. "Development of Venture Investments", Online: http://www.technologyfunding.com.

7. "Ebay Quote and General Financial Information", Online: http://quicken.excite.com.

8. "Ebay Press Release”, September 24, 1998, Online:

http://pages.ebay.com/community/ aboutebay/releases.

9. "Ebay 10-K Financial Statements", December 31, 1988, Online: http://pages.ebay.com.

10. "Stages in the Venture Capital Investment Process", Entrepreneurship and Small Business Office, Online: http://strategis.ic.gc.ca/SSG/soIO1899e.html.

11. Ewing, Terzah, "IPO Market Set a Slew of Records in 1999, A Large, Small Offerings Hit Home Runs", The Wall Street Journal, Dow Jones Company, Inc., January 3, 2000, Pages R4, R8.

12. Frick, Robert, "IPOs For the Rest of Us", May 1, 1998, Online: www.kiplinger.com. 
13. “Goldman Sachs Prospectus for IPO”, May 3, 1999, Online: www.gs.com/investor-information.

14. "Leading Underwriters for Initial Public Offerings in 2000", Online: http://www.ipo.com.

15. Malkiel, Burton, A Randam Walk Down Wall Street, W.W. Norton and Company, New York, 1996.

16. Price Waterhouse Cooper Money Tree Report, 1999, Online: www.pricewaterhousecooper, moneytree.com.

17. Rabinovitz, Jonathon, “1999 VC Funding Tops \$21 Billion”, November 1999, Online www.thestandard.com.

18. Ritter, Jay R. , "The Long-Run Performance of Initial Public Offerings", Journal of Finance, Volume 46, Number 1, March 1991, Pages 3-27.

19. Scannell, "IPO Rocket Lands as Investors Prefer Profits to Pipe Dreams", The Wall Street Journal, Dow Jones Company Inc., January 2, 2001, Page R6.

20. Stallman, Chris, "Goldman Sachs IPO: Proof That Not Every IPO Is a New Company", May 10, 1999, Online: www.buckinvestor.com.

21. "The Pitch: The Underwriting Underdog", May 1, 1999, Online: www.business2.com.

22. "Top Ten Underwriters of Debt and Equity in 2000”, The Wall Street Journal, Dow Jones Company Inc., January 3, 2001, Page R19.

23. “UPS 10-Q Financial Statements", September 9, 1000, Online: http://medis.corporate-ir.net.

24. "UPS Prospectus For IPO”, November 10, 1999, Online: http://www.freedegar.com.

25. "Venture Capital", 2000, Online: http://www.investorhome.com/vc.htm.

26. Yahoo Finance, 1999 and 2000, Online: www.yahoo.com.

\section{Notes}

